\title{
Exploring Packaged Microvesicle Proteome Composition of Chinese Hamster Ovary Secretome
}



Haldar', Jonathan Pillai ${ }^{1}$, Shinjini Bhatnagar ${ }^{11}$ and Susmita Chaudhuri ${ }^{1 * \#}$

${ }^{1}$ Centre for Biodesign and Diagnostics (CBD), Translational Health Science and Technology Institute (THSTI), Faridabad, Haryana, India

${ }^{2}$ School of Life Sciences, Jawaharlal Nehru University, New Delhi, India

\#Contributed equally

\begin{abstract}
Background: Chinese Hamster Ovary cells $(\mathrm{CHO})$ are the most preferred host cells to meet the increasing demand for high quality 'human-like' complex biologics production, but is faced with the challenge of achieving high yield at an affordable price. Secreted proteins critically impact cell growth and product quality and quantity and an integral part of secretome is the packaged microvesicles. In spite of numerous efforts to characterize spent-media proteome, none have identified specific contribution of microvesicles, necessitating further differential analysis of these defined fractions of spent-media proteome, specifically packaged microvesicles.
\end{abstract}

Methods: We have investigated proteome of microvesicles isolated from lag, log, stationary and death phase of $\mathrm{CHO}$ batch culture using LC-MS/MS based-proteomic approach to identify proteins that may be involved in regulation of cell growth, viability and productivity in culture.

Results: A total of 89 unique proteins were identified in the microvesicles isolated from lag, log, stationary and death-phase of culture; of these only $8.9 \%$ were categorized as secretory proteins leaving $\sim 91 \%$ proteins of intracellular and non-secretory nature. Microvesicles were observed to contain a number of culture phase-specific proteins which included cell-signaling molecules, transcription and translation regulators and molecular chaperons: many of which are known growth regulators, indicating the potency of microvesicles in regulating culture health.

Conclusions: This is the first report of $\mathrm{CHO}$ microvesicular proteome and this knowledge is critical in developing rationale design of perfusion process, downstream purification process for rendering improved product stability and also novel cell engineering approaches to maximize growth and improved media formulations to maximize yield and minimize product degradation.

Keywords: CHO; Proteome; Microvesicles; Secretome; Recombinant protein production

Abbreviations: LC-MS/MS: Liquid Chromatography Mass Spectrometry; CHO: Chinese Hamster Ovary.

\section{Introduction}

Chinese Hamster Ovary $(\mathrm{CHO})$ cells are the preferred host cell line for the production of recombinant protein therapeutics and monoclonal antibodies, accounting for more than $70 \%$ of all current therapeutics with over $\$ 99$ billion in market value $[1,2]$. Though $\mathrm{CHO}$ cells have been successfully scaled up to produce 5-10 g/L biologics [3], further improvements in the production are of eminent importance to meet the global demand at affordable cost. This could be achieved mainly by three ways; 1 - improve production capability of cells in culture (improved cell specific productivity, cell density and culture longevity), 2- minimize product degradation and heterogeneity, 3improve product purification process

It is known for a long time that proteins/peptides present in the spent-media could regulate various bioprocess-related phenotypes including cell growth, quality and quantity of recombinant protein product. For example, a number of growth-regulating factors (such as Fibroblast Growth Factor (FGF), Hepatocyte Growth Factor (HGF), Leukemia Inhibitory Factor (LIF), Vascular Endothelial Growth Factor $\mathrm{C}$ (VEGF-C) and transferrin) have been identified in spent-culture media of $\mathrm{CHO}$ cells, whose supplementation in the culture media enhances the cell growth in culture $(\sim 48 \%)$ even at low cell density and improves the performance of production culture [4]. On the other hand, a number of proteolytic enzymes (matrix metallopeptidase 3
(MMP3), MMP10, MMP12 and cathepsin-B) have been identified in culture media which may pose risk for proteolytic-degradation of the product leading to low yield from production batches [5,6]. Besides, efficient removal of these peptides/proteins along with other Host Cell Proteins (HCPs) from the final product during down-stream processing is mandatory for product safety and/or longer shelf-life. Majorly there are three sources for these type of peptides/proteins in the spentmedia, a) proteins/peptides directly secreted by the healthy cells into the culture media, b) proteins/peptides packed into microvesicles (like exosomes (30-100 nm), microvesicles (100-1000 nm)) for transducing signal to other cells in the culture and/or c) proteins/peptides leaked into the culture media from damaged/dead cells. To date, a number of studies have been performed to identify spent-media proteome $[4,6,7]$, however they were never designed to identify and differentiate proteins directly secreted/leaked from the cells from packed in microvesicles. Microvesicles have already been shown to increase or reduce cell

*Corresponding author: Susmita Chaudhuri, Centre for Biodesign and Diagnostics (CBD), Translational Health Science and Technology Institute (THSTI) NCR Biotech Science Cluster, 3rd Milestone, Faridabad-Gurgaon Expressway, PO Box \#04, Faridabad-121 001, Haryana, India, Tel: 0129-287-6300; E-mail: susmita@thsti.res.in

Received February 25, 2016; Accepted March 30, 2016; Published April 04, 2016

Citation: Kumar N, Gupta DG, Kumar S, Maurya P, Tiwari A, et al. (2016) Exploring Packaged Microvesicle Proteome Composition of Chinese Hamster Ovary Secretome. J Bioprocess Biotech 6: 274. doi:10.4172/2155-9821.1000274

Copyright: $\odot 2016$ Kumar N, et al. This is an open-access article distributed under the terms of the Creative Commons Attribution License, which permits unrestricted use, distribution, and reproduction in any medium, provided the original author and source are credited. 
proliferation and hence have capabilities to regulate bioprocess-related cellular phenotypes (like cell growth, yield and product stabilization) in production culture [8-10]. They may be enriched or deprived for specific proteins, based on their functional purpose and their cellular origin and this could be responsible for its dynamic effect on cells. The microvesicles purified from the supernatant of T24 bladder cancer cells were enriched for B-cell lymphoma 2 (Bcl-2) and cyclin D1 (antiapoptotic proteins), but deprived for BCL2-Associated X Protein (Bax) and caspase-3 proteins (pro-apoptotic proteins) contributing towards immunity against programmed cell-death by cancerous cells [11]. Moreover, the amount of secreted microvesicles has also been correlated with the expression of phosphorylated protein kinase B (Ak) $\mathrm{t}$ and extracellular signal-regulated protein kinases (ERKs) which are crucial elements regulating apoptosis and cell differentiation processes. The microvesicles have also been shown to be enriched for multiple proteolytic enzymes, like MMP-2 and MMP-14 [12,13]. Though these enzymes are important for various cellular processes, they could also impact the quality and quantity of the product in culture. Besides, microvesicular proteins also contribute to HCPs which need to be removed from product during product purification steps.

Therefore in this investigation, we aimed to reveal the proteome of microvesicles specifically since they are also an integral part of the secretome. For this, $\mathrm{CHO}$ cells were grown in chemically-defined protein-free culture medium in shake flask and microvesicles were isolated using ultracentrifugation method over lag, log, stationary and death phase of batch culture. The purified microvesicles were investigated using gel-free proteomics tools (LC-LTQ Orbitrap MS) in order to identify microvesicular proteins that may have impact on cell growth, viability and/or productivity and also better define HCP.

\section{Materials and Methods}

\section{Cell culture}

Suspension-adapted CHO-K1 cells were grown in chemicallydefined, protein-free medium, CD-CHO media (Gibco, Life Technologies) supplemented with $6 \mathrm{mM}$ glutamine. Cells were seeded at $0.2 \times 10^{6}$ viable cells $/ \mathrm{mL}$ in $250 \mathrm{~mL}$ shake-flask (Erlenmeyer flask, Corning) with working volume of $100 \mathrm{~mL}$ and maintained at 120 $\mathrm{rpm}$ at $37^{\circ} \mathrm{C}$ in $\mathrm{CO}_{2}$ incubator. The cell counts and viability assays were performed at every 24 hours (hrs.) interval using trypan-blue (Amresco) dye exclusion method with hematocytometer and data was utilized to plot the growth curve.

\section{Microvesicles isolation and sample preparation}

Conditioned media was collected after day 2, 4, 6 and 8 reflecting lag, log, stationary and death phase of culture. The microvesicles were isolated using ultracentrifugation methods. Briefly, media was centrifuged at $1000 \mathrm{rpm}$ for 5 minutes to remove cells from sample. The supernatant was collected in fresh $50 \mathrm{~mL}$ tubes and was again centrifuged at $10000 \mathrm{rpm}$ for 20 minutes at $4^{\circ} \mathrm{C}$ to remove dead cells and cellular debris. The supernatant was collected and then finally centrifuged (Beckmann Coulter SW40T) at 100,000 g for 60 minutes. The pellet (microvesicles) was re-suspended in $7 \mathrm{M}$ urea based lysis buffer ( $7 \mathrm{M}$ urea, $2 \mathrm{M}$ thiourea, $30 \mathrm{mM}$ Tris, $4 \%$ CHAPS, $5 \mathrm{mM}$ magnesium acetate, $\mathrm{pH}$ 8.5) after washing twice with ice-cold PBS by ultracentrifugation at $100,000 \mathrm{~g}$ for 60 minutes. The gradual centrifugation is of importance to minimize breakage of cellular debris due to high centrifugation forces during ultracentrifugation and potential contamination of debrisassociated proteins to microvesicular fraction. Protein concentration was determined using the thiourea-compatible Bradford (Amresco Pure Protein Grade) protein assay (Bio-Rad XMark Microplate
Spectrophotometer). Approximately $50 \mu \mathrm{g}$ microvesicular protein was achieved from $300 \mathrm{~mL}$ of conditioned media collected after 4 days of culture.

\section{Microvesicle analysis}

Western blot analysis: Protein $(5 \mu \mathrm{g})$ was separated using $10 \%$ SDS polyacrylamide gels and transferred onto nitrocellulose membranes (PAL Corporation Biotrace NT) using the semi-dry transfer method. Membranes were blocked with 5\% Marvel-PBS for $1 \mathrm{hr}$ at room temperature and probed overnight at $4^{\circ} \mathrm{C}$ with rabbit anti-CD63 antibodies (Santa-cruz, SC-15363). Blots were then washed and incubated with peroxidase-labelled anti-rabbit secondary antibodies (anti-rabbit IgG-HRP, Cell Signalling, 70745). After washing, bands specific for microvesicular marker were confirmed by the Enhanced Chemiluminescence (ECL) method (GE Healthcare) with Gel Doc ${ }^{\text {ma }}$ XR (Bio-Rad). Coomasie stained gel was used as a loading control.

Particle size determination: Microvesicular fraction was evaluated for particle size by Dynamic Light Scattering (DLS) techniques using Zeta-sizer, (Nano-ZS-90, Malvern Instruments, USA) and analyzed by DTS Nano software. Ultra-pure water was used as a dispersant medium. Microvesicular samples isolated using ultracentrifugation method for biological triplicates were diluted with aqueous Phosphate Buffer Saline (PBS) solution and were confirmed for particle size.

\section{In-solution protein digestion}

Protein samples were dissolved in $50 \mathrm{mM}$ ammonium bicarbonate $\left(\mathrm{NH}_{4} \mathrm{HCO}_{3}\right)$ solution to a final concentration of $0.1 \mu \mathrm{g} / \mu \mathrm{l}$. Lyophilized trypsin was dissolved in ice cold $1 \mathrm{mM}$ acetonitrile (ACN) to achieve final working concentration of $13 \mathrm{ng} / \mu \mathrm{l}$ and $\mathrm{pH}$ of $\sim 8.5$ was adjusted using $50 \mathrm{mM} \mathrm{NH} \mathrm{HCO}_{3}$. The trypsin was then added to result in a protein-to-trypsin ratio of 1:30, and enzymatic digestion was carried out at $37^{\circ} \mathrm{C}$ for overnight. For LC-MS/MS analysis, the resulting peptide mixtures were diluted in $5 \%$ Formic acid ( $\mathrm{v} / \mathrm{v}$ in water) to $0.067 \mu \mathrm{g} / \mu \mathrm{l}$.

\section{Nano LC-MS/MS and data analysis}

For LC-LTQ Orbitrap MS analysis, samples were re-solubilized in $2 \%[\mathrm{v} / \mathrm{v}]$ acetonitrile, $0.1 \%[\mathrm{v} / \mathrm{v}]$ formic acid in water and injected onto the trap column at a flow rate of $20 \mu \mathrm{l} / \mathrm{min}$ subsequently peptides were separated on Zorbax 300SB-C18 (Agilent, Santa Clara, CA, USA) by a gradient developed from $2 \%[\mathrm{v} / \mathrm{v}]$ acetonitrile, $0.1 \%[\mathrm{v} / \mathrm{v}]$ formic acid to $80 \%[\mathrm{v} / \mathrm{v}$ ] acetonitrile, $0.1 \%[\mathrm{v} / \mathrm{v}]$ formic acid in water over 180 min at a flow rate of $300 \mathrm{nl} / \mathrm{min}$ onto an Agilent 1200 (Agilent, Santa Clara, CA, USA) nano-flow LC-System that was in-line coupled to the nano-electrospray source of a LTQ-Orbitrap discovery hybrid mass spectrometer (Thermo Scientific, San Jose, CA, USA). Full MS in a mass range between $\mathrm{m} / \mathrm{z} 300-2,000$ was performed in the Orbitrap mass analyzer with a resolution of 30,000 at $\mathrm{m} / \mathrm{z} 400$ and an AGC target of $2 \times$ $10^{5}$. The strongest five signals were selected for CID (collision induced dissociation)-MS/MS in the LTQ ion trap at a normalized collision energy of 35\% using an AGC target of $1 \times 10^{5}$ and two micro scans. Dynamic exclusion was enabled with one repeat counts during $45 \mathrm{~s}$ and an exclusion period of $180 \mathrm{~s}$. Peptide identification was performed by CID-based MS/MS of the selected precursors. For protein/peptide identification, MS/MS data were searched against the Cricetulus griseus amino acid sequence database using an in-house Mascot server (version 2.4) through the Proteome Discoverer 1.4 software. The search was set up for full tryptic peptides with a maximum of three missed cleavage sites. Carbamidomethyl on cysteine, and oxidized methionine were included as variable modifications. The precursor mass tolerance threshold was $10 \mathrm{ppm}$, and the maximum fragment mass error was 
$0.8 \mathrm{Da}$. The confident identifications were screened using following criteria; (i) proteins with $\geq 2$ peptides matched, and (ii) a MASCOT score $\geq 30$ and (iii) identified in all three biological replicates.

\section{Cellular localization analysis}

Protein sequences were fetched from NCBI database for all identified proteins and were used for evaluating protein localization using web-based freely available tools for protein localization, CELLO (http://cello.life.nctu.edu.tw/; version-2.5), NgLOc (http://genome. unmc.edu/ngLOC/index.html; version-1.0), SignalP (http://www.cbs. dtu.dk/services/SignalP/; version 4.1). The data obtained was used for comparative analysis for protein localization.

\section{Results}

\section{Cell growth}

Suspension-adapted $\mathrm{CHO}-\mathrm{K} 1$ cells were seeded at $0.2 \times 10^{6}$ cells/ $\mathrm{mL}$ in chemically-defined, protein-free medium, $\mathrm{CD}-\mathrm{CHO}$ medium in shake flask and maintained at $37^{\circ} \mathrm{C}$ over the batch culture. The cell counts and viability assays were performed every day and data for three biological replicates was utilized to plot the growth curve. Different phase of growth (lag, log, stationary and decline phase) were clearly reflect during the culture in growth curve (Figure 1). Highest viable cell concentration was achieved at day- 6 of the culture $\left(6.5 \pm 0.6 \times 10^{6}\right.$ viable cells $/ \mathrm{mL}$ ) with maintained high culture viability $(95.2 \pm 1.3 \%)$. The cell-free conditioned media was harvested from all three biological replicate flasks after day 2, 4, 6 and 8 reflecting lag, log, stationary and death phase of culture and utilized to harvest micro vesicle using gradual centrifugation approach.

\section{Quality analysis of microvesicles}

Western blot analysis was performed using proteins from microvesicular fraction using anti-CD63 antibody to ensure the quality of microvesicular samples before proceeding for mass-spectrometry for proteome identification. CD63 is a know marker for microvesicles [15]. Western blot analysis clearly indicated that CD63 was present in all three biological replicate samples suggesting the presence of microvesicular proteins in the microvesicle protein fraction (Figure 2). Besides during size analysis, only single peak (avaraged at $255.87 \pm 6.12$ $\mathrm{nm}$ ) was observed in all biological replicates suggesting microsomal enrichment in the sample and hence supporting the quality of the microsomal sample for further proteomic analysis (Table 1).

\section{In-solution protein digestion}

Protein samples were dissolved in $50 \mathrm{mM} \mathrm{NH}_{4} \mathrm{HCO}_{3}$ solution to a final concentration of $0.1 \mu \mathrm{g} / \mu \mathrm{l}$. DTT was added (final concentration 1 $\mathrm{mM}$ ) and incubated at $60^{\circ} \mathrm{C}$ for $15 \mathrm{~min}$ followed by incubation whilst protected from light in the presence of $5 \mathrm{mM}$ iodoacetamide at $4^{\circ} \mathrm{C}$. Lyophilized trypsin was dissolved in ice cold $1 \mathrm{mM} \mathrm{HCl}$ to achieve final working concentration of $13 \mathrm{ng} / \mu \mathrm{l}$ and $\mathrm{pH}$ of $\sim 8.5$ was adjusted using 50 $\mathrm{mM}$ ammonium bicarbonate. The trypsin was then added to result in a protein-to-trypsin ratio of 1:30, and enzymatic digestion was carried out at $37^{\circ} \mathrm{C}$ for overnight. For LC-MS/MS analysis, the resulting peptide mixtures were diluted in 5\% Formic acid (v/v in water) to $0.067 \mu \mathrm{g} / \mu \mathrm{l}$.

\section{Nano LC-MS/MS and data analysis}

For LC-LTQ Orbitrap MS analysis, samples were re-solubilized in $2 \%[\mathrm{v} / \mathrm{v}]$ acetonitrile, $0.1 \%[\mathrm{v} / \mathrm{v}]$ formic acid in water and injected onto the trap column at a flow rate of $20 \mu \mathrm{l} / \mathrm{min}$ subsequently peptides were separated on Zorbax 300SB-C18 (Agilent, Santa Clara, CA, USA) by a gradient developed from $2 \%[\mathrm{v} / \mathrm{v}]$ acetonitrile, $0.1 \%[\mathrm{v} / \mathrm{v}]$ formic acid to $80 \%$ [v/v] acetonitrile, $0.1 \%$ [v/v] formic acid in water over $180 \mathrm{~min}$ at a flow rate of $300 \mathrm{nl} / \mathrm{min}$ onto an Agilent 1200 (Agilent, Santa Clara, CA, USA) nano-flow LC-System that was in-line coupled to the nano-electrospray source of a LTQ-Orbitrap discovery hybrid mass spectrometer (Thermo Scientific, San Jose, CA, USA). Full MS in a mass range between $\mathrm{m} / \mathrm{z} 300-2,000$ was performed in the Orbitrap mass analyzer with a resolution of 30,000 at $\mathrm{m} / \mathrm{z} 400$ and an AGC target of 2 $\times 10^{5}$. The strongest five signals were selected for CID (collision induced dissociation)-MS/MS in the LTQ ion trap at a normalized collision energy of $35 \%$ using an AGC target of $1 \times 10^{5}$ and two micro scans. Dynamic exclusion was enabled with one repeat counts during $45 \mathrm{~s}$ and an exclusion period of $180 \mathrm{~s}$. Peptide identification was performed by CID-based MS/MS of the selected precursors. For protein/peptide identification, MS/MS data were searched against the Cricetulus griseus amino acid sequence database using an in-house Mascot server (version 2.4) through the Proteome Discoverer 1.4 software. The search was set up for full tryptic peptides with a maximum of three missed cleavage sites. Carbamidomethyl on cysteine, and oxidized methionine were included as variable modifications (Figure 3). The precursor mass tolerance threshold was $10 \mathrm{ppm}$, and the maximum fragment mass error was $0.8 \mathrm{Da}$. The significance threshold of the ion score was calculated based on a false discovery rate of $<1 \%$, estimated by the peptide validator node of the Proteome Discoverer software. The confident identifications were screened using following criteria; (i) proteins with $\geq 2$ peptides matched, and (ii) a MASCOT score $\geq 30$ and (iii) identified in all three biological replicates.

\section{Microvesicular protein identification}

A total of 31 proteins from lag-phase, 80 from log-phase, 48 from stationary-phase and 60 from death-phase were identified by following criteria of mascot search score $\geq 30$, at least $\geq 2$ peptides used for identification and identified in all three biological replicate samples (Table 2). This cumulatively resulted into identification of 89 unique proteins in the microvesicles isolated from lag, log, stationary and death-phase of culture (Table 3 ).

The proteins identified in microvesicles collected from lag, log, stationary and death-phase were also overlapped in order to identify phase-specific and process-related proteins (Figure 4 ). The analysis revealed that 10 proteins were only identified in lag-phase, 16 in logphase, 2 in stationary-phase and 5 in death-phase. A total of 15 proteins were identified in all the culture-phase (lag, log, stationary and deathphase) indicating them to be process-related.

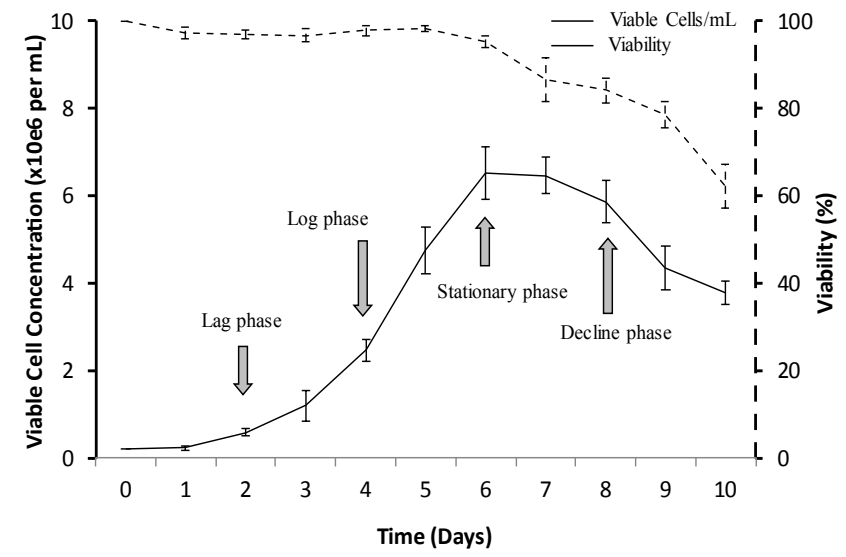

Figure 1: Growth curve of suspension-adapted $\mathrm{CHO}-\mathrm{K} 1$ cells cultured in serum-free and chemically defined media. Error bars represent the standard deviation calculated using three biological replicate batch cultures. 


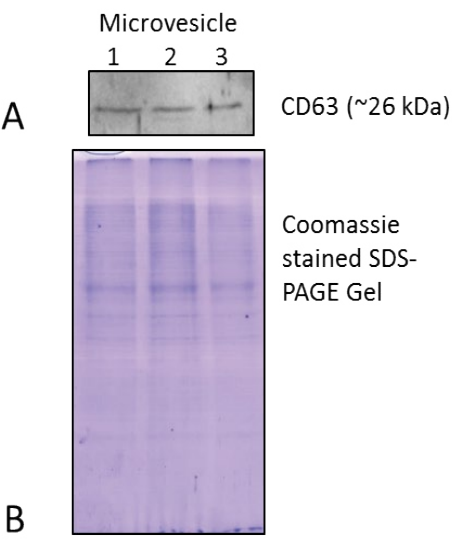

Figure 2: Western blot analysis of proteins samples from microvesicles; $A$ Western blot analysis with anti-CD63 antibody for microvesicular fraction after ultracentrifugation (biological triplicates). B: Coomasie staining of microvesicular fraction in SDS-PAGE (biological triplicates).

\begin{tabular}{|l|l|l|l|l|}
\hline Parameter & $\begin{array}{l}\text { Biological } \\
\text { Replicate-1 }\end{array}$ & $\begin{array}{l}\text { Biological } \\
\text { Replicate-1 }\end{array}$ & $\begin{array}{l}\text { Biological } \\
\text { Replicate-1 }\end{array}$ & $\begin{array}{l}\text { Average } \\
\text { (Standard } \\
\text { Deviation) }\end{array}$ \\
\hline Size (d.nm) & 254 & 262.7 & 250.9 & $255.87(6.12)$ \\
\hline Width (d.nm) & 47.71 & 45.88 & 45.17 & $46.25(1.31)$ \\
\hline Intensity (\%) & 100 & 100 & 100 & 100 \\
\hline
\end{tabular}

A Particle size D $(90 \%)$ represents number distribution pattern.

Values reported are mean \pm S.D. $(n=3)$

Table 1: Particle size analysis of microvesicles.

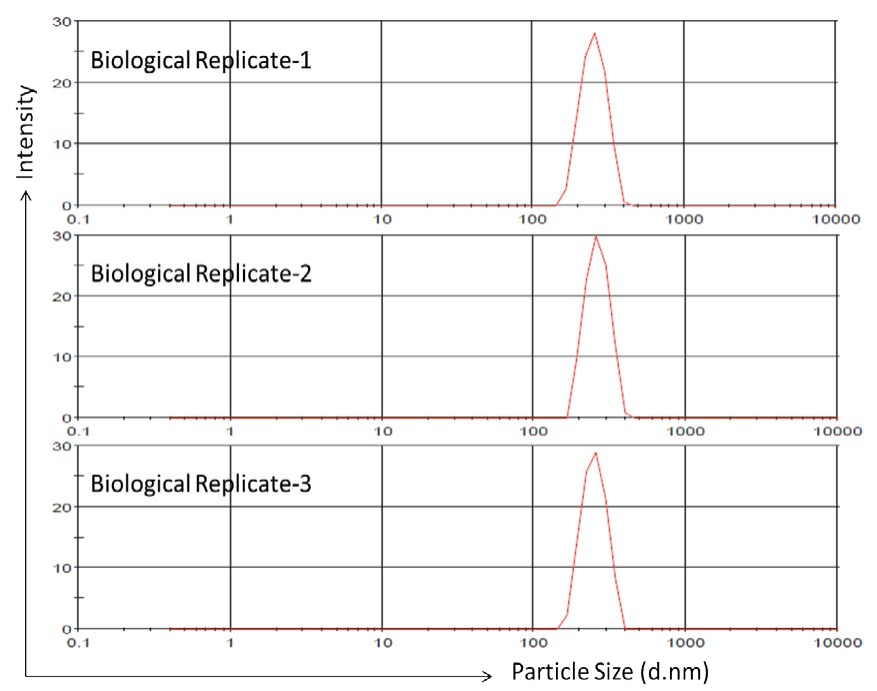

Figure 3: Particle size analysis of microvesicular fractions (biological triplicates).

\section{Microvesicular protein localization analysis}

All 89 unique proteins were extensively evaluated to categorize them into secretory and/or non-secretory groups using published literature and bioinformatics tools. The protein predicted to be secretory by all three algorithm used for the purpose was considered as secretory protein. Interestingly, based on the criteria, only 8 proteins $(8.9 \%)$ were identified as secretory by all three algorithms suggesting that $>91 \%$ proteins packed in microvesicles were intracellular and nonsecretory in nature (Table 4 and Figure 5).

\section{Functional analysis of microvesicular proteins}

Identified proteins were further analyzed for its functional categorization and found to be majorly of the following types: structural proteins (28\%), metabolic proteins (16\%), cell signaling proteins $(17 \%)$, transcription factors (5\%) and translation factors (4\%) and molecular chaperons (7\%) (Figure 6). Other functional categories included stress response, proteasomal degradation complex etc.

\section{Discussion}

Chinese Hamster Ovary (CHO) cells are the most commonly used host cell line for the production of recombinant protein therapeutics and antibodies $[1,2]$. These products are typically expensive because of high production cost. Though efforts are being made constantly to improve the yield from $\mathrm{CHO}$ production cultures to meet increasing demand of high-quality and affordable products, we are still far away in terms of achieving production capability of natural producer cells (plasma cells). This is mainly because we still know very little about CHO cells and their behavior in production cultures and hence are able to utilize just a fraction of their potential for the purpose. Thus there is a need to focus more on understanding CHO cells, the components/ biomolecules present in the microenvironment of production culture and their dynamic interaction to be enabled in developing rationale cell engineering approaches and media formulation strategies to improve performance of the production process.

To date majority of studies executed on $\mathrm{CHO}$ cells have focused on understanding the cellular physiology in respect to recombinant protein production capabilities [16-19]. The proteins/peptides present in surroundings (spent-media) have largely remained unknown yet, though they have already been known to impact bioprocess-related phenotypes including cell growth and quality and quantity of recombinant protein products. The spent-media may have proteins/peptides which are directly secreted into the culture media by the cells, packed into the microvesicles (like exosomes) for transducing signal to other cells in the culture and/or leaked into the culture media from damaged or dying cells. The proteins directly secreted or leaked into culture media have direct contact with the cells and product in the culture and hence could be expected to have direct impact on cell growth behavior and quality and quantity of the product. Whereas, proteins packed in the microvesicles could regulate cell number by controlling cell proliferation or death in production culture and hence could also impact overall yield. Hence knowledge of both, packed or nonpacked proteins is of great importance for efficient process control and improving overall yield.

A few efforts have been made to reveal the proteome of $\mathrm{CHO}$ spent-media $[4,6,7]$; however they have never been focused to identify and differentiate packed vs. non-packed proteins though their purpose of origin and mechanism of action towards impacting cell growth and recombinant protein production could be immensely distinct. Besides, differentiation between proteins secreted from healthy cells vs. leaked from damaged or dead cells from packed in microvesicles is also extremely important in designing downstream processing strategies and ultimately to better understand secretome.

Therefore in this investigation we aimed to reveal the proteome of $\mathrm{CHO}$ microvesicles using gel-free proteomics tools (LC-LTQ

\begin{tabular}{|c|c|c|c|c|}
\hline \multicolumn{4}{|c|}{ Phase of Culture } & \multirow{2}{*}{$\begin{array}{c}\text { Number of identified Unique } \\
\text { Proteins }\end{array}$} \\
\hline Lag & Log & Stationary & Death & \\
\hline 31 & 80 & 48 & 60 & 89 \\
\hline
\end{tabular}

Table 2: Number of proteins identified in microvesicles isolated from lag, log stationary and death-phase of $\mathrm{CHO}$ culture. 
Citation: Kumar N, Gupta DG, Kumar S, Maurya P, Tiwari A, et al. (2016) Exploring Packaged Microvesicle Proteome Composition of Chinese Hamster Ovary Secretome. J Bioprocess Biotech 6: 274. doi:10.4172/2155-9821.1000274

Page 5 of 11

\begin{tabular}{|c|c|c|c|c|c|c|c|c|c|}
\hline \multirow{2}{*}{ S No. } & Accession & Description & Gene Symbol & Score & Coverage & Peptides & AAs & MW [kDa] & calc. pl \\
\hline & \multicolumn{9}{|l|}{ Structural } \\
\hline 1 & 347360906 & Actin, cytoplasmic 1 & ACTB & 149.59 & 17.6 & 6 & 375 & 41.7 & 5.39 \\
\hline 2 & 354492323 & Moesin & MSN & 54.27 & 3 & 2 & 566 & 66.5 & 6.28 \\
\hline 3 & 354482483 & Vimentin & VIM & 283.18 & 14.16 & 8 & 466 & 53.7 & 5.12 \\
\hline 4 & 354503280 & Annexin A2-like, partial & ANXA2 & 220.87 & 39.65 & 8 & 227 & 25.4 & 5.97 \\
\hline 5 & 354501786 & Cofilin-1-like & CFL1 & 106.65 & 30.72 & 3 & 166 & 18.5 & 8.09 \\
\hline 6 & 354489212 & Myosin-Ic-like isoform 1 & MYO1C & 163.56 & 7.49 & 5 & 1028 & 118.1 & 9.38 \\
\hline 7 & 345842430 & Tubulin alpha-1B chain & TUBA1B & 129.5 & 12.64 & 4 & 451 & 50.1 & 5.06 \\
\hline 8 & 354472141 & Alpha-actinin-1 & ACTN1 & 79.43 & 2.58 & 2 & 931 & 107.5 & 5.39 \\
\hline 9 & 354504022 & Myosin-9 & MYH9 & 434.54 & 7.5 & 11 & 1880 & 217.6 & 5.64 \\
\hline 10 & 354496812 & Annexin A1-like & ANXA1 & 202.12 & 21.1 & 6 & 346 & 38.8 & 7.02 \\
\hline 11 & 354482221 & Annexin A11 & ANXA11 & 81.65 & 4.57 & 2 & 503 & 54.1 & 7.65 \\
\hline 12 & 354491741 & Annexin A4-like isoform 1 & ANXA4 & 78.41 & 13.17 & 3 & 319 & 35.8 & 5.57 \\
\hline 13 & 354497282 & Actin, cytoplasmic 2-like, partial & ACTG1 & 149.59 & 18.97 & 6 & 348 & 38.5 & 5.36 \\
\hline 14 & 354490960 & Ezrin & EZR & 437.42 & 14.89 & 9 & 638 & 74.9 & 6.89 \\
\hline 15 & 354481554 & Prelamin-A/C-like isoform 1 & LMNA & 143.58 & 6.63 & 4 & 664 & 73.9 & 7.81 \\
\hline 16 & 354481232 & Radixin & RDX & 54.27 & 2.92 & 2 & 583 & 68.5 & 6.27 \\
\hline 17 & 354483018 & $\begin{array}{l}\text { Basement membrane-specific } \\
\text { heparan sulfate proteoglycan core } \\
\text { protein }\end{array}$ & HSPG2 & 173.12 & 2.06 & 7 & 4412 & 471.6 & 6.54 \\
\hline 18 & 354473830 & Tropomyosin alpha-1 chain-like & TPM1 & 377.6 & 35.21 & 10 & 284 & 32.8 & 4.75 \\
\hline 19 & 354478924 & $\begin{array}{l}\text { Tropomyosin alpha-3 chain-like } \\
\text { isoform } 3\end{array}$ & TPM3 & 405.59 & 35.08 & 10 & 248 & 28.9 & 4.75 \\
\hline 20 & 354500481 & Filamin-A & FLNA & 448.02 & 8.83 & 13 & 2538 & 268.8 & 5.9 \\
\hline 21 & 354481182 & Filamin-B isoform 2 & FLNB & 168.01 & 2.73 & 5 & 2603 & 277.7 & 5.74 \\
\hline 22 & 354494381 & Fibronectin isoform 1 & FN1 & 183.15 & 3.59 & 7 & 2480 & 272.7 & 5.63 \\
\hline 23 & 354472895 & Histone H4-like & HIST1H4A & 80.76 & 29.13 & 3 & 103 & 11.4 & 11.36 \\
\hline 24 & 354483672 & $\begin{array}{l}\text { Spectrin beta chain, brain } 1 \text { isoform } \\
1\end{array}$ & SPTBN1 & 137.69 & 2.37 & 4 & 2363 & 274 & 5.59 \\
\hline \multirow[t]{2}{*}{25} & 354501005 & Lactadherin-like, partial & MFGE8 & 195.72 & 37.93 & 5 & 174 & 19.9 & 8.65 \\
\hline & \multicolumn{9}{|l|}{ Metabolism } \\
\hline 1 & 354496013 & $\begin{array}{l}\text { Fatty acid-binding protein, } \\
\text { adipocyte-like }\end{array}$ & FABP4 & 124.41 & 24.24 & 4 & 132 & 14.7 & 7.93 \\
\hline 2 & 354473486 & $\begin{array}{l}\text { Pyruvate kinase isozymes M1/M2- } \\
\text { like isoform } 1\end{array}$ & PKM & 182.09 & 17.14 & 6 & 531 & 57.9 & 7.27 \\
\hline 3 & 354499945 & Alpha-enolase & ENO1 & 245.84 & 16.78 & 5 & 429 & 46.7 & 6.16 \\
\hline 4 & 349501082 & $\begin{array}{l}\text { Glyceraldehyde-3-phosphate } \\
\text { dehydrogenase }\end{array}$ & GAPDH & 171.5 & 13.51 & 3 & 333 & 35.7 & 8.34 \\
\hline 5 & 354474551 & Acyl-CoA-binding protein-like & $\mathrm{DBI}$ & 190.54 & 28.74 & 3 & 87 & 10 & 8.82 \\
\hline 6 & 354472325 & Tubulointerstitial nephritis antigen & TINAGL1 & 53.31 & 5.59 & 2 & 465 & 52.5 & 7.08 \\
\hline 7 & 354476904 & $\begin{array}{l}\text { Sodium/potassium-transporting } \\
\text { ATPase subunit alpha-1 }\end{array}$ & ATP1A1 & 134.37 & 5.65 & 4 & 1116 & 123 & 5.53 \\
\hline 8 & 354468711 & Cathepsin Z & CTSZ & 118.16 & 13.4 & 3 & 306 & 34 & 7.58 \\
\hline 9 & 354478439 & $\begin{array}{l}\text { Nucleoside diphosphate kinase } \\
\text { B-like }\end{array}$ & NME2 & 162.48 & 35.53 & 5 & 152 & 17.3 & 7.99 \\
\hline 10 & 350537635 & $\begin{array}{l}\text { 4F2 cell-surface antigen heavy } \\
\text { chain }\end{array}$ & SLC3A2 & 142.27 & 15.01 & 4 & 533 & 58.9 & 5.47 \\
\hline 11 & 346227178 & L-lactate dehydrogenase $\mathrm{A}$ chain & LDHA & 124.31 & 14.16 & 4 & 332 & 36.5 & 7.42 \\
\hline 12 & 354472752 & Cytochrome c, somatic-like & CYCS & 71.43 & 20.95 & 2 & 105 & 11.7 & 9.51 \\
\hline 13 & 354482641 & $\begin{array}{l}\text { Delta-aminolevulinic acid } \\
\text { dehydratase }\end{array}$ & ALAD & 183.01 & 17.58 & 5 & 330 & 36.1 & 6.98 \\
\hline \multirow[t]{2}{*}{14} & 354497685 & Pantetheinase & VNN1 & 73.08 & 5.47 & 2 & 512 & 56.7 & 5.63 \\
\hline & \multicolumn{9}{|l|}{ Cell Signaling } \\
\hline 1 & 354469007 & $\begin{array}{l}\text { Rho GDP-dissociation inhibitor } \\
\text { 1-like }\end{array}$ & ARHGDIA & 237.74 & 31.86 & 4 & 204 & 23.4 & 5.2 \\
\hline 2 & 354496917 & Calmodulin-like & CALM1 & 984.41 & 22.26 & 6 & 265 & 29.1 & 4.75 \\
\hline 3 & 354466994 & $\begin{array}{l}\text { Phosphatidylethanolamine-binding } \\
\text { protein 1-like }\end{array}$ & PEBP1 & 214.21 & 49.2 & 5 & 187 & 20.9 & 7.53 \\
\hline 4 & 354478483 & Caltractin-like & CETN2 & 984.41 & 18.79 & 6 & 314 & 34.8 & 5.82 \\
\hline 5 & 354478978 & Protein S100-A6-like & S100A6 & 467.41 & 28.09 & 2 & 89 & 10 & 5.48 \\
\hline
\end{tabular}


Citation: Kumar N, Gupta DG, Kumar S, Maurya P, Tiwari A, et al. (2016) Exploring Packaged Microvesicle Proteome Composition of Chinese Hamster Ovary Secretome. J Bioprocess Biotech 6: 274. doi:10.4172/2155-9821.1000274

Page 6 of 11

\begin{tabular}{|c|c|c|c|c|c|c|c|c|c|}
\hline 6 & 354484391 & 14-3-3 protein zeta/delta-like & YWHAZ & 165.18 & 22.86 & 4 & 245 & 27.7 & 4.79 \\
\hline 7 & 354476375 & Transforming protein RhoA-like & RHOA & 65.91 & 13.47 & 2 & 193 & 21.8 & 6.1 \\
\hline 8 & 354501872 & $\begin{array}{l}\text { Rho-related GTP-binding protein } \\
\text { RhoC-like }\end{array}$ & $\mathrm{RHOB}$ & 65.91 & 13.47 & 2 & 193 & 22 & 6.58 \\
\hline 9 & 354487034 & Macrophage-capping protein-like & CAPG & 111.01 & 10.03 & 2 & 349 & 38.7 & 6.73 \\
\hline 10 & 354471813 & $\begin{array}{l}\text { EH domain-containing protein } 4 \text {, } \\
\text { partial }\end{array}$ & EHD4 & 57.66 & 3.69 & 2 & 515 & 58.6 & 6.58 \\
\hline 11 & 350539723 & $\begin{array}{l}\text { Guanine nucleotide-binding protein } \\
\mathrm{G}(\mathrm{I}) / \mathrm{G}(\mathrm{S}) / \mathrm{G}(\mathrm{T}) \text { subunit beta-1 }\end{array}$ & GNB1 & 166.79 & 13.82 & 4 & 340 & 37.4 & 6 \\
\hline 12 & 354508126 & 14-3-3 protein epsilon-like, partial & YWHAE & 103.43 & 33.33 & 3 & 105 & 11.9 & 5.83 \\
\hline 13 & 354494229 & $\begin{array}{l}\mathrm{SH} 3 \text { domain-binding glutamic acid- } \\
\text { rich-like protein-like }\end{array}$ & SH3BGRL & 144.62 & 74.56 & 5 & 114 & 12.7 & 5.07 \\
\hline 14 & 354495613 & Thrombomodulin-like & THBD & 68.15 & 6.24 & 2 & 577 & 61.9 & 4.69 \\
\hline \multirow[t]{2}{*}{15} & 354482553 & Thrombospondin-1 & THBS1 & 268.51 & 8.89 & 8 & 1170 & 129.6 & 4.93 \\
\hline & \multicolumn{9}{|c|}{ Transcription } \\
\hline 1 & 354475571 & NSFL1 cofactor p47-like isoform 1 & NSFL1C & 105.33 & 12.1 & 3 & 372 & 41 & 5.2 \\
\hline 2 & 537153542 & $\begin{array}{l}\text { Bromodomain adjacent to zinc } \\
\text { finger domain protein } 1 \mathrm{~A}\end{array}$ & BAZ1A & 89.58 & 2.39 & 3 & 2011 & 228.4 & 6.09 \\
\hline 3 & 537191106 & $\begin{array}{l}\text { Nuclear factor related to kappa-B- } \\
\text { binding protein }\end{array}$ & NFRKB & 34.07 & 0.6 & 1 & 2505 & 275.9 & 7.68 \\
\hline \multirow[t]{2}{*}{4} & 354502621 & $\begin{array}{l}\text { Nuclease-sensitive element-binding } \\
\text { protein 1-like }\end{array}$ & YBX1 & 231.37 & 21.36 & 4 & 337 & 38.3 & 10.15 \\
\hline & \multicolumn{9}{|l|}{ Translation } \\
\hline 1 & 346227155 & Elongation factor 2 & EEF2 & 110.3 & 3.61 & 3 & 858 & 95.3 & 6.83 \\
\hline 2 & 354486063 & Clusterin-like & CLU & 67.54 & 7.42 & 2 & 445 & 51.5 & 5.85 \\
\hline 3 & 346986359 & Elongation factor 1 -alpha 1 & EEF1A1 & 95.09 & 8.44 & 2 & 462 & 50.1 & 9.01 \\
\hline \multirow[t]{2}{*}{4} & 354495391 & $\begin{array}{l}\text { 60S acidic ribosomal protein P2- } \\
\text { like }\end{array}$ & RPLP2 & 60.2 & 24.35 & 2 & 115 & 11.7 & 4.54 \\
\hline & \multicolumn{9}{|c|}{ Proteosomal Degradation Complex } \\
\hline 1 & 350540096 & $\begin{array}{l}\text { Lysosome-associated membrane } \\
\text { glycoprotein } 1\end{array}$ & LAMP1 & 146.08 & 9.34 & 3 & 407 & 43.8 & 6.71 \\
\hline 2 & 354494438 & Sulfated glycoprotein 1 & PSAP & 126.27 & 7.53 & 3 & 598 & 65.7 & 5.49 \\
\hline 3 & 354468731 & $\begin{array}{l}\text { Proteasome subunit alpha type- } \\
\text { 7-like }\end{array}$ & PSMA7 & 112.06 & 7.59 & 2 & 382 & 41.7 & 9.61 \\
\hline 4 & 346986300 & Polyubiquitin & UBB & 64.28 & 31.31 & 2 & 1038 & 116.6 & 8.38 \\
\hline 5 & 354473967 & $\begin{array}{l}\text { Ubiquitin-60S ribosomal protein } \\
\text { L40-like isoform } 1\end{array}$ & UBA52 & 64.28 & 19.53 & 2 & 128 & 14.7 & 9.83 \\
\hline 6 & 354483686 & $\begin{array}{l}\text { Ubiquitin-40S ribosomal protein } \\
\text { S27a-like }\end{array}$ & RPS27A & 64.28 & 16.03 & 2 & 156 & 17.9 & 9.6 \\
\hline \multirow[t]{2}{*}{7} & 537136494 & $\begin{array}{l}\text { Ubiquitin carboxyl-terminal } \\
\text { hydrolase } 5 \text { isoform } 2\end{array}$ & USP5 & 41.67 & 2.47 & 2 & 1051 & 116.4 & 5.12 \\
\hline & \multicolumn{9}{|c|}{ Stress Response } \\
\hline 1 & 354466320 & Superoxide dismutase [Cu-Zn]-like & SOD1 & 114.63 & 14.88 & 2 & 242 & 25.9 & 9.55 \\
\hline 2 & 350537945 & Peroxiredoxin-1 & PRDX1 & 60.01 & 12.56 & 3 & 199 & 22.2 & 8.05 \\
\hline 3 & 354487462 & $\begin{array}{l}\text { Thioredoxin reductase } 1 \text {, } \\
\text { cytoplasmic }\end{array}$ & TXNRD1 & 431.06 & 24.88 & 10 & 611 & 67.2 & 7.8 \\
\hline 4 & 354470385 & Catalase & CAT & 121.73 & 6.83 & 3 & 527 & 60 & 7.68 \\
\hline 5 & 354507545 & Glutathione S-transferase Mu 1-like & GSTM1 & 76.36 & 10.09 & 2 & 218 & 25.5 & 6.37 \\
\hline 6 & 354506476 & Glutathione S-transferase Mu 7-like & GSTM7 & 76.36 & 10.09 & 2 & 218 & 25.9 & 7.37 \\
\hline \multirow[t]{2}{*}{7} & 350537543 & Glutathione S-transferase P 1 & GSTP1 & 107.27 & 12.38 & 2 & 210 & 23.6 & 7.8 \\
\hline & \multicolumn{9}{|c|}{ Cell adhesion } \\
\hline 1 & 354496408 & Galectin-1-like & LGALS1 & 67.81 & 24.44 & 2 & 135 & 14.8 & 5.8 \\
\hline 2 & 350539683 & Intercellular adhesion molecule 1 & ICAM1 & 119.38 & 9.3 & 4 & 527 & 57.6 & 7.24 \\
\hline 3 & 354473282 & Galectin-3-binding protein-like & LGALS3BP & 130.62 & 10.8 & 4 & 574 & 63.8 & 5.19 \\
\hline \multirow[t]{2}{*}{4} & 537201836 & $\begin{array}{l}\text { Hyaluronan and proteoglycan link } \\
\text { protein } 3\end{array}$ & HAPLN3 & 356.88 & 18.05 & 13 & 881 & 97.9 & 7.62 \\
\hline & \multicolumn{9}{|c|}{ Protein folding (molecular chaperones) } \\
\hline 1 & 354483044 & $\begin{array}{l}\text { Peptidyl-prolyl cis-trans isomerase } \\
\text { A-like }\end{array}$ & PPIA & 145.54 & 22.56 & 3 & 164 & 17.9 & 8.28 \\
\hline 2 & 354474350 & $\begin{array}{l}\text { Peptidyl-prolyl cis-trans isomerase } \\
\text { B-like }\end{array}$ & PPIB & 80.95 & 12.5 & 2 & 216 & 23.6 & 9.58 \\
\hline 3 & 350537423 & $78 \mathrm{kDa}$ glucose-regulated protein & HSPA5 & 344.8 & 22.48 & 12 & 654 & 72.3 & 5.16 \\
\hline 4 & 350539823 & Heat shock cognate $71 \mathrm{kDa}$ protein & HSPA8 & 146.65 & 12.07 & 5 & 646 & 70.8 & 5.36 \\
\hline
\end{tabular}


Citation: Kumar N, Gupta DG, Kumar S, Maurya P, Tiwari A, et al. (2016) Exploring Packaged Microvesicle Proteome Composition of Chinese Hamster Ovary Secretome. J Bioprocess Biotech 6: 274. doi:10.4172/2155-9821.1000274

Page 7 of 11

\begin{tabular}{|c|c|c|c|c|c|c|c|c|c|}
\hline 5 & 350540064 & Heat shock protein HSP 90 -alpha & HSP90AA1 & 85.04 & 5.59 & 3 & 733 & 84.8 & 5.03 \\
\hline \multirow[t]{2}{*}{6} & 354479029 & $\begin{array}{l}\text { Heat shock protein HSP 90-beta- } \\
\text { like }\end{array}$ & HSP90AB1 & 140.59 & 7.04 & 4 & 724 & 83.1 & 5.02 \\
\hline & \multicolumn{9}{|c|}{ Miscellaneous } \\
\hline 1 & 354480912 & Basigin & BSG & 245.79 & 13.45 & 4 & 409 & 44.6 & 6.2 \\
\hline 2 & 354501595 & $\begin{array}{l}\text { Complement regulatory protein } \\
\text { Crry-like }\end{array}$ & CD59 & 88.75 & 11.16 & 2 & 421 & 46.6 & 7.64 \\
\hline 3 & 354485425 & Platelet glycoprotein 4-like & CD36 & 63.15 & 7.42 & 2 & 472 & 52.9 & 8.56 \\
\hline
\end{tabular}

Table 3: List of identified unique proteins in microvesicles isolated from $\mathrm{CHO}$ batch culture.

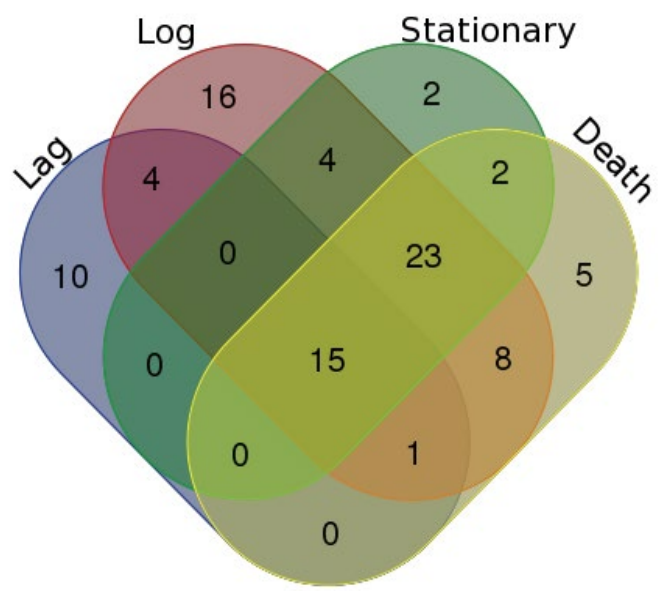

\begin{tabular}{|c|c|c|}
\hline Culture Phase & $\begin{array}{c}\text { Total } \\
\text { Proteins }\end{array}$ & Identity of Protein(s) \\
\hline Lag & 10 & $\begin{array}{l}\text { RHOB, RHOA, ACTN1, GSTM1, EHD4, GSTM7, TUBA1B, HSP90AA1, } \\
\text { CD59 and VNN1 }\end{array}$ \\
\hline $\log$ & 16 & $\begin{array}{l}\text { USP5, LAMP1, HAPLN3, CFL1, CD36, EEF2, NFRKB, TINAGL1, UBA52, } \\
\text { RPS27A, FN1, UBB, ATP1A1, BAZ1A, YWHAE and RPLP2 }\end{array}$ \\
\hline Stationary & 2 & CTSZ and PSMA7 \\
\hline Death & 5 & $\begin{array}{l}\text { SH3BGRL, MYH9, LMNA, ALAD and CAT } \\
\end{array}$ \\
\hline Lag, Log & 4 & SLC3A2, GSTP1, EEF1A1 and MYO1C \\
\hline Log, Stationary & 4 & TPM3, FABP4, THBS1 and EZR \\
\hline Log, Death & 8 & HSP90AB1, LDHA, NME2, CAPG, SPTBN1, SOD1, LGALS1 and FLNB \\
\hline Stationary, Death & 2 & YBX1 and PPIB \\
\hline Lag, Log, Death & 1 & ANXA1 \\
\hline $\begin{array}{l}\text { Log, Stationary, } \\
\text { Death }\end{array}$ & 23 & $\begin{array}{l}\text { CETN2, CYCS, ENO1, DBI, FLNA, HSPA5, PEBP1, PPIA, MYH9, GAPDH, } \\
\text { ANXA11, S100A6, NSFL1C, HIST1H4A, BSG, TPM1, GNB1, TXNRD1, } \\
\text { VIM, YWHAZ, CALM1, ARHGDIA and PSAP, }\end{array}$ \\
\hline $\begin{array}{l}\text { Lag, Log, Stationary, } \\
\text { Death }\end{array}$ & 15 & $\begin{array}{l}\text { ACTB, ANXA2, HSPG2, MFGE8, HSPA8, CLU, RDX, ICAM1, ANXA4, } \\
\text { MSN, PKM, THBD, ACTG1, LGALS3BP and PRDX1 }\end{array}$ \\
\hline
\end{tabular}

Figure 4: Overlapping of proteins identified in microvesicles isolated from lag, log, stationary and death-phase of $\mathrm{CHO}$ Batch Culture.

\begin{tabular}{|c|c|c|c|}
\hline S No & Accession & Description \\
\hline 1 & 537201836 & Hyaluronan and proteoglycan link protein 3 \\
\hline 2 & 354496408 & Galectin-1-like & HAPLN3 \\
\hline 3 & 354494381 & Fibronectin isoform 1 \\
\hline 4 & 354473282 & Galectin-3-binding protein-like & ThN1 \\
\hline 5 & 354482553 & Thrombospondin-1 \\
\hline 6 & 354468711 & Cathepsin Z \\
\hline 7 & 354497685 & Pantetheinase \\
\hline 8 & 354472325 & CTSZ \\
\hline
\end{tabular}

Table 4: List of microvesicular proteins predicted to be secretory in nature. 


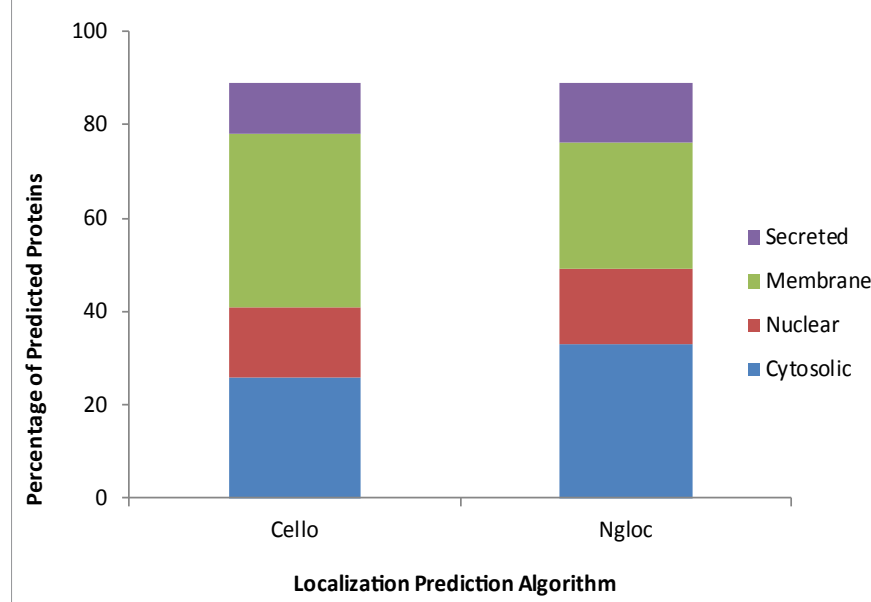

Figure 5: Prediction of cellular Localization of microvesicular proteins by predictive bioinformatics tools.



Figure 6: Functional categories of microvesicular proteins.

Orbitrap MS). To the best of our knowledge, this is the first report of the microvesicular proteome of $\mathrm{CHO}$ cells. A total of 89 proteins were identified in the $\mathrm{CHO}$ microvesicles collected from the exponentially growing cells. Though higher number of proteins have been identified in microvesicles from human samples, smaller number has also been identified in other cell lines; 41 in microvesicles from SKBR3, 43 proteins in microvesicles from BT474 and 59 in microvesicles from MCF7 $[20,21]$ suggesting that the number of identified protein may vary from cell line to cell line. All the identified were also mapped with ExoCarta (www.exocarta.org), a database for microvesicular proteins [22]. All the proteins identified were observed to be present in ExoCarta database suggesting that the microvesicular proteins are highly conserved along mammalian species.

\section{Cellular localization analysis of microvesicular proteins}

Only 8 proteins $(8.9 \%)$ were categorized as secretory proteins by all three different bioinformatics tools used, leaving $~ 91 \%$ of microvesicular proteins intracellular and non-secretory nature in microvesicles (Table 4 and Figure 5). This is in-line with published literature reporting $\sim 90 \%$ of the identified proteins in microvesicles to be non-secretory in nature $[20,23]$. This suggests that the protein which cannot be secreted through classical cell secretion pathway but are required to serve any specific purpose by donor/receiving cell could be packed into the intracellular membranous vesicles, like exosomes, and transferred from one to another and hence is one of the method used for cell-to-cell communication.

Besides, identification of proteome of microvesicles is important because significant numbers of intracellular and non-secretory proteins are being identified in spent-media and considered part of secretome, though are non-secretory in nature. For example, $\sim 88 \%$ of the identified proteins in suspension culture in the spent-media of $\mathrm{CHO}$ cells were categorized as intracellular and non-secretory by Lim et al. and $\sim 78 \%$ by Valente et al., although the viability of culture under investigation was above $95 \%[4,24]$. This is mainly because majority of the studies designed to identify secreted proteins in media have been able to remove only large sized microvesicles (centrifuge sample $\leq 10000$ $\mathrm{rpm}$ or filter with $0.45 \mu \mathrm{m}$ filter) leaving the high proportion of small microvesicles $(\sim 200 \mathrm{~nm})$, including exosomes, in the culture media. These microvesicles carry intracellular cargo, including intracellular and non-secretory proteins, which lead towards identification of significant number of intracellular and non-secretory proteins along with truly secreted proteins in the sample. Therefore, identification of microvesicular proteome of $\mathrm{CHO}$ cells could be of great help in better differentiation of secretory proteins from the intracellular and nonsecretory proteins packed in microvesicles.

\section{Functional analysis of microvesicular proteins}

Like cells, structural proteins (actin, vimentin, tubulins, annexins, cofilins, and filamins) were observed to be abundant (28\%) in microvesicular proteome which could be expected to maintain mechanical coupling between cytoskeletal microtubules and actin microfilaments which ultimately could be preserving shape, size and integrity of microvesicles (Table 3 and Figure 6) [25]. Adhesion molecules, such as galectin-1 (LGALS1) like, intracellular adhesion molecule 1 (ICAM1) and hyaluronan and proteoglycan link protein 3 (HAPLN3), were also observed in the microvesicles. These proteins may be associated in adhesion and efficient delivery of their cargo of microvesicles to recipient cells [26,27]. Hence knowledge of structural proteins and adhesion molecules of microvesicles is of immense importance to understand microvesicles, their mechanism to deliver intracellular cargo to recipient cell(s) and impact biological process effectively.

Besides, the microvesicles were observed to contain proteins involved and/or associated with regulation of wide variety of cellular process, such as transcription, translation, cellular stress and protein folding which, upon delivery of microvesicular content to recipient cells, could enable to regulate various biological process including folding and secretion of recombinant protein product, cell proliferation and cell death in the culture (Table 3 and Figure 6). For example, nuclease-sensitive element-binding protein 1 (YBX1)-like protein was identified in microvesicular fraction. YBX1 is known to be involved in many cellular functions including transcription/translation, alternative splicing, mRNA degradation/processing in P-bodies including small RNA processing and function $[28,29]$. YBX1 has been shown to induce the expression of pro-proliferative genes (such as epidermal growth factor receptor, cyclin $A$, and cyclin B) and hence induce cell proliferation in the culture [30]. Superoxide dismutase 1 (SOD1), a cellular stress regulator, catalyzes the conversion of superoxide ion $\left(\mathrm{O}_{2}^{-}\right)$into $\mathrm{H}_{2} \mathrm{O}_{2}$ and $\mathrm{O}_{2}$ to maintain low levels of Reactive Oxygen Species (ROS). Overexpression of SOD1 has been reported to induce cell proliferation 
without affecting cell cycle progression and lower the apoptosis of lung carcinoma cell lines (H358 and H1975 cells) which promotes growth by increasing survival [31]. Regulation of cellular process, such as cell proliferation and cell death, is of imminence importance in designing of efficient bioprocess and hence identification of microvesicular proteome is of obvious importance.

The overlapping of proteins identified in microvesicles isolated from lag, log, stationary and death phase of cultured enabled identification of 10 lag-phase specific proteins, 16 log-phase specific, 2 stationary phase specific and 5 death-phase specific proteins (Figure 4). The presence of phase-specific protein suggests that microvesicles may contain specific proteins based on physiological state of cells at the time of microvesicle origin and their functional purpose; and this could be responsible for its dynamic effect on cells. The lag-phase specific proteins mainly contained cell signaling proteins (Ras homolog gene family, member A (RHOA), Ras homolog gene family, member B (RHOB) and EH domain-containing protein 4 (EHD4)) followed by structural proteins (Alpha-actinin-1 (ACTN1) and Tubulin alpha-1B (TUBA1B)) and stress response proteins (Glutathione S-transferase Mu 1 (GSTM1) and Glutathione S-transferase Mu 7 (GSTM7)). RHOA and RHOB are known to regulate cell proliferation [32,33]. The structural proteins also plays crucial role in cell proliferation [34]. Hence, the presence of cell-proliferation regulation-associated cell signaling and structural proteins could be linked with the preparation of cells for higher rate of proliferation in the upcoming log-phase. Cells in lag phase have been reported to high intercellular stress level compared to cells in $\log$, stationary and death-phase [35]. The stress proteins present in the microvesicles could be expected to be associated with regulation of intracellular stress in lag-phase of culture. Microvesicles from log phase were mainly enriched with proteins involved in proteosomal protein degradation pathway (Polyubiquitin (UBB), Ubiquitin-60S ribosomal protein L40 (UBA52), Ubiquitin-40S ribosomal protein S27a (RPS27A), Ubiquitin carboxyl-terminal hydrolase 5 (USP5), Lysosome-associated membrane glycoprotein 1 (LAMP1)). Ubiquitin (UBB) has a major role in targeting cellular proteins for degradation by the $26 \mathrm{~S}$ proteasome, but it is also involved in the maintenance of chromatin structure, regulation of gene expression, and stress response. The overexpression of UBB has been observed to induce cell proliferation and henceforth inhibitors of UBB are being explored as potential therapy for various cancers [36]. It could also fuse with ribosomal proteins S27a (RPS27A) and L40 (UBA52). Both (UBA80 and UBA52) were also observed to be packed in microvesicles. Ubiquitin acts as a chaperone for its fusion partners and hence its presence is critical for proper ribosome biogenesis and thereof mRNA translation [37]. This is in line with the observation where exogenous expression of RPS27A has already been shown to induce cell proliferation whereas inhibition reduced the cell viability, induced cell cycle arrest at $\mathrm{S}$ and $\mathrm{G} 2 / \mathrm{M}$ phases and increased cell apoptosis in the culture [38]. Whereas, inhibition of UBA52 didn't showed similar effects on cellular health as expression of only $\sim 7 \%$ mRNAs was observed to be altered suggesting transcript-specific translation by the UBA52 [39]. This could be important for recombinant protein production as low temperature has been believed to cause transcript-specific translation and hence improve overall yield from the cultures $[18,39,40]$. USP5 is involved in disassembly of conjugated ubiquitin to maintain proteasome function and its availability for other functions [41]. Besides, two transcription factor (Nuclear factor related to kappa-B-binding protein (NFRKB) and Bromodomain adjacent to zinc finger domain protein $1 \mathrm{~A}(\mathrm{BAZ1A}))$ and two translational factors (Elongation factor 2 (EEF2) and 60S acidic ribosomal protein P2 (RPLP2)) were also identified in microvesicles isolated from log-phase of $\mathrm{CHO}$ culture further suggesting potential impact of microvesicles on receiver's translational status. Microvesicles from stationary-phase has only two unique proteins, Cathepsin Z (CTSZ; metabolic protein) and Proteasome subunit alpha type-7 (PSMA7; proteosomal protein degradation pathway associated protein), whereas death-phase microvesicles had two structural (Myosin-9 (MYH9) and Prelamin-A/C (LMNA)) [42-44], one metabolic (Delta-aminolevulinic acid dehydratase (ALAD)), one cell signaling ( $\mathrm{SH} 3$ domain-binding glutamic acid-rich-like protein (SH3BGRL)) and one stress response (Catalase (CAT)) protein unique [45].

A total of 15 proteins were identified in microvesicles isolated from all phases of culture, lag, log, stationary and death-phase. Besides being potentially integral part of the microvesicles in terms of structure, function, delivery and/or their genesis, these proteins could be significantly contributing to the host cell proteins which need to be removed during down-stream processing. Of the 15,8 proteins were structural proteins (Actin cytoplasmic 1 (ACTB), Annexin A2 (ANXA2), heparan sulfate proteoglycan (HSPG2), Lactadherin (MFGE8), Radixin (RDX), Annexin A4 (ANXA4), Moesin (MSN) and Actin cytoplasmic 2 (ACTG1)); potentially required for maintenance of microvesicular shape, size and integrity [46-48]. Two adhesion molecules (Intercellular adhesion molecule 1 (ICAM1) and Galectin-3-binding protein (LGALS3BP)) were also present which could be associated with delivery of the microvesicular content into the recipient cells.

Hence the knowledge of microvesicular proteome is of great importance in order to identify proteins that may regulate cell growth and recombinant protein product in culture as well as the proteins that need to be removed during down-stream processing. This knowledge would enable development of rationale cell engineering and media formulation approaches to improve performance of the $\mathrm{CHO}$ based bioprocess.

\section{Conclusion}

$\mathrm{CHO}$ cells are the most commonly used cell lines for production of recombinant protein therapeutics. Microvesicles are small membranous vesicles that are released by various cell types, including $\mathrm{CHO}$, into the culture as integral part of spent-media proteome. The microvesicles transfer biomolecular cargo from one cell to another and hence could regulate various cellular phenotypes, including cell growth, cell-death and recombinant protein production; efficient regulation of all of these phenotypes is of utmost importance for achieving higher yield from production culture. To date, a number of efforts have been made to identify spent-media proteome of $\mathrm{CHO}$ cells; however microvesicles specifically and exclusively have not been explored though recent publications have proven the importance of microvesicles in regulation of various bioprocess-related phenotypes. Therefore in this investigation, we have explored the proteome of $\mathrm{CHO}$ microvesicles collected from the lag, log, stationary and death phase of $\mathrm{CHO}$ batch culture. Microvesicles were observed to contain a number of phase-specific proteins suggesting the dynamic nature and effects of microvesicles on bioprocess. The microvesicles from log-phase have a number of proteins, phase-specific proteins (proteosomal protein degradation pathway associated proteins (UBB, UBA52, RPS27A, USP5 and LAMP1) and transcription (NFRKB, BAZ1A) and translation regulators (EEF2, RPLP2)) which are already known to be associated with regulation of cell growth in culture. Whereas, lag-phase specific proteins mainly contained cell signaling proteins (RHOA, RHOB and EHD4) followed by structural proteins (ACTN1 and TUBA1B) and stress response proteins (GSTM1 and GSTM7). These could be linked with 
the preparation of cells for higher rate of proliferation in the upcoming log-phase. A number of proteins were identified in microvesicles isolated from all phases of culture, lag, log, stationary and death-phase. Besides being potentially integral part of the microvesicles in terms of structure, function, delivery and/or their genesis, these proteins could be significantly contributing to the host cell proteins which need to be removed during down-stream processing.

Henceforth the investigation of microvesicular proteome may help to identify proteins that may enable improved regulation of cell growth and productivity in bioprocess and development of efficient downstream processing approaches.

\section{Competing Interest Statement}

The authors declare no financial or commercial conflict of interest regarding this work.

\section{Authors' Contribution}

NK, SBh and SC designed, supervised and executed the entire study. NK and SC contributed to writing of the manuscript. SK and PM carried out the mass spec analysis, data compilation and database identification of proteins and ratios. $\mathrm{SBa}$ JP and BM carried out the quality analysis of exosomes. NK and DGG carried out all cell culture and fractionation work. SBh, AT and SH contributed intellectually to many aspects of the study. All authors contributed to revising and approving the final manuscript.

\section{Acknowledgements}

The work was supported by core grants of the Translational Health Science and Technology Institute supported by The Department of Biotechnology, Ministry of Science and Technology, Government of India. We thank the MS facility of the Centre for Cellular and Molecular Platforms (CCAMP), Bangalore, India for their help in our study.

\section{References}

1. Kim JY, Kim YG, Lee GM (2012) CHO cells in biotechnology for production of recombinant proteins: current state and further potential. Appl Microbio Biotechnol 93: 917-930.

2. Walsh G (2010) Biopharmaceutical benchmarks 2010. Nat Biotechnol 28: 917 924.

3. Lim Y, Wong NS, Lee YY, Ku SC, Wong DC, et al. (2010) Engineering mammalian cells in bioprocessing - current achievements and future perspectives. Biotechnol Appl Biochem 55: 175-189.

4. Lim UM, Yap MG, Lim YP, Goh LT, Ng SK (2013) Identification of autocrine growth factors secreted by $\mathrm{CHO}$ cells for applications in single-cell cloning media. J Proteome Res 12: 3496-3510.

5. Sandberg H, Lütkemeyer D, Kuprin S, Wrangel M, Almstedt A, et al. (2006) Mapping and partial characterization of proteases expressed by a $\mathrm{CHO}$ production cell line. Biotechnol Bioeng 95: 961-971.

6. Slade PG, Hajivandi M, Bartel CM, Gorfien SF (2012) Identifying the CHO secretome using mucin-type O-linked glycosylation and click-chemistry. J Proteome Res 11: 6175-6186.

7. Dorai H, Liu S, Yao X, Wang Y, Tekindemir U, et al. (2013) Proteomic Analysis of Bioreactor Cultures of an Antibody Expressing CHO-GS Cell Line that Promotes High Productivity. J Proteomics Bioinform 6: 099-108.

8. Xiao H, Lässer C, Shelke GV, Wang J, Rådinger M, et al. (2014) Mast cell exosomes promote lung adenocarcinoma cell proliferation - role of KIT-stem cell factor signaling. Cell Commun Signal 12: 64 .

9. Harris DA, Patel SH, Gucek M, Hendrix A, Westbroek W, et al. (2015) Exosomes released from breast cancer carcinomas stimulate cell movement. PLoS One 10: e0117495.

10. Flanagan J, Middeldorp J, Sculley T (2003) Localization of the Epstein-Barr virus protein LMP 1 to exosomes. J Gen Virol 84: 1871-1879.

11. Yang L, Wu XH, Wang D, Luo CL, Chen LX (2013) Bladder cancer cell-derived exosomes inhibit tumor cell apoptosis and induce cell proliferation in vitro. Mol Med Rep 8: 1272-1278.
12. Han KY, Dugas-Ford J, Seiki M, Chang JH, Azar DT (2015) Evidence for the Involvement of MMP14 in MMP2 Processing and Recruitment in Exosomes of Corneal Fibroblasts. Invest Ophthalmol Vis Sci 56: 5323-5329.

13. Hoshino D, Kirkbride KC, Costello K, Clark ES, Sinha S, et al. (2013) Exosome secretion is enhanced by invadopodia and drives invasive behavior. Cell Rep 5: 1159-1168

14. Chaudhuri S, Maurya P, Kaur M, Tiwari A, Borth N, et al. (2015) Investigation of $\mathrm{CHO}$ Secretome: Potential Way to Improve Recombinant Protein Production from Bioprocess. J Bioprocess Biotech 5: 240.

15. Caby MP, Lankar D, Vincendeau-Scherrer C, Raposo G, Bonnerot C (2005) Exosomal-like vesicles are present in human blood plasma. Int Immunol 17 879-887.

16. Meleady P, Doolan P, Henry M, Barron N, Keenan J, et al. (2011) Sustained productivity in recombinant Chinese hamster ovary $(\mathrm{CHO})$ cell lines: proteome analysis of the molecular basis for a process-related phenotype. BMC Biotechnol 11: 78.

17. Meleady P, Henry M, Gammell P, Doolan P, Sinacore M, et al. (2008) Proteomic profiling of $\mathrm{CHO}$ cells with enhanced rhBMP-2 productivity following co-expression of PACEsol. Proteomics 8: 2611-2624.

18. Baik JY, Lee MS, An SR, Yoon SK, Joo EJ, et al. (20036) Initial transcriptome and proteome analyses of low culture temperature-induced expression in $\mathrm{CHO}$ cells producing erythropoietin. Biotechnology and Bioengineering 93: 361-371.

19. Kumar N, Gammell P, Meleady P, Henry M, Clynes M (2008) Differential protein expression following low temperature culture of suspension $\mathrm{CHO}-\mathrm{K} 1$ cells. BMC Biotechnol 8: 42.

20. Klinke DJ 2nd, Kulkarni YM, Wu Y, Byrne-Hoffman C (2014) Inferring alterations in cell-to-cell communication in HER2+ breast cancer using secretome profiling of three cell models. Biotechnol Bioeng 111: 1853-1863.

21. Kruger S, Abd Elmageed ZY, Hawke DH, Wörner PM, Jansen DA, et al. (2014) Molecular characterization of exosome-like vesicles from breast cancer cells. BMC Cancer 14: 44

22. Mathivanan S, Fahner CJ, Reid GE, Simpson RJ (2012) ExoCarta 2012: database of exosomal proteins, RNA and lipids. Nucleic Acids Res 40: D1241-1244.

23. Pisitkun T, Shen RF, Knepper MA (2004) Identification and proteomic profiling of exosomes in human urine. Proc Natl Acad Sci U S A 101: 13368-13373.

24. Valente KN, Schaefer AK, Kempton HR, Lenhoff AM, Lee KH (2014) Recovery of Chinese hamster ovary host cell proteins for proteomic analysis. Biotechno J 9: 87-99.

25. Rodolfo C, Piacentini M (2002) Does cytoskeleton 'Akt' in apoptosis? Cell Death Differ 9: 477-478.

26. Morelli AE, Larregina AT, Shufesky WJ, Sullivan ML, Stolz DB, et al. (2004) Endocytosis, intracellular sorting, and processing of exosomes by dendritic cells. Blood 104: 3257-3266.

27. Marcus ME, Leonard JN (2013) FedExosomes: Engineering Therapeutic Biological Nanoparticles that Truly Deliver. Pharmaceuticals (Basel) 6: 659 680.

28. Evdokimova V, Ruzanov P, Anglesio MS, Sorokin AV, Ovchinnikov LP, et al. (2006) Akt-mediated YB-1 phosphorylation activates translation of silent mRNA species. Mol Cell Biol 26: 277-292.

29. Dutertre M, Sanchez G, De Cian MC, Barbier J, Dardenne E, et al. (2010) Cotranscriptional exon skipping in the genotoxic stress response. Nat Struct Mol Biol 17: 1358-1366.

30. Wu L, Fan J, Belasco JG (2006) MicroRNAs direct rapid deadenylation of mRNA. Proc Natl Acad Sci U S A 103: 4034-4039.

31. Somwar R, Erdjument-Bromage H, Larsson E, Shum D, Lockwood WW, et al. (2011) Superoxide dismutase 1 (SOD1) is a target for a small molecule identified in a screen for inhibitors of the growth of lung adenocarcinoma cell lines. Proc Natl Acad Sci U S A 108: 16375-16380

32. Faried A, Faried LS, Kimura H, Nakajima M, Sohda M, et al. (2006) RhoA and RhoC proteins promote both cell proliferation and cell invasion of human oesophageal squamous cell carcinoma cell lines in vitro and in vivo. Eur $\mathrm{J}$ Cancer 42: 1455-1465

33. Chen YX, Li ZB, Diao F, Cao DM, Fu CC, et al. (2006) Up-regulation of RhoB by glucocorticoids and its effects on the cell proliferation and NF-kappaB transcriptional activity. J Steroid Biochem Mol Biol 101: 179-187. 
Citation: Kumar N, Gupta DG, Kumar S, Maurya P, Tiwari A, et al. (2016) Exploring Packaged Microvesicle Proteome Composition of Chinese Hamster Ovary Secretome. J Bioprocess Biotech 6: 274. doi:10.4172/2155-9821.1000274

34. Tang DD (2015) Critical role of actin-associated proteins in smooth muscle contraction, cell proliferation, airway hyperresponsiveness and airway remodeling. Respir Res 16: 134

35. Taschwer M, Hackl M, Hernández Bort JA, Leitner C, Kumar N, et al. (2012) Growth, productivity and protein glycosylation in a $\mathrm{CHO}$ EpoFc producer cell line adapted to glutamine-free growth. J Biotechnol 157: 295-303.

36. Oh C, Park S, Lee EK, Yoo YJ (2013) Downregulation of ubiquitin leve via knockdown of polyubiquitin gene Ubb as potential cancer therapeutic intervention. Sci Rep 3: 2623

37. Archibald JM, Teh EM, Keeling PJ (2003) Novel ubiquitin fusion proteins: ribosomal protein P1 and actin. J Mol Biol 328: 771-778.

38. Wang H, Yu J, Zhang L, Xiong Y, Chen S, et al. (2014) RPS27a promotes proliferation, regulates cell cycle progression and inhibits apoptosis of leukemia cells. Biochem Biophys Res Commun 446: 1204-1210.

39. Lee AS, Burdeinick-Kerr R, Whelan SP (2013) A ribosome-specialized translation initiation pathway is required for cap-dependent translation of vesicular stomatitis virus mRNAs. Proc Natl Acad Sci U S A 110: 324-329.

40. Barron N, Kumar N, Sanchez N, Doolan P, Clarke C, et al. (2011) Engineering $\mathrm{CHO}$ cell growth and recombinant protein productivity by overexpression of miR-7. J Biotechnol 151: 204-211.

41. Ristic G, Tsou WL, Guzi E, Kanack AJ, Scaglione KM, et al. (2016) USP5 is dispensable for mono-ubiquitin maintenance in Drosophila. J Biol Chem.
42. Lin KW, Souchelnytskyi S (2010) Eukaryotic elongation factor eEF1A1 promotes and Ser300 mutants of eEF1A1 inhibit transition through the $S$ and G2/M phases of the cell cycle. J Cell Mol Biol 8: 125-130.

43. Nguan CY, Guan Q, Gleave ME, Du C (2014) Promotion of cell proliferation by clusterin in the renal tissue repair phase after ischemia-reperfusion injury. Am J Physiol Renal Physiol 306: F724-733.

44. Shuangta X, Yali H, Zhengrong Z, Qingquan Z, Xiaoshan Z, et al. (2014) Knockdown of CETN1 inhibits breast cancer cells proliferation. J BUON 19 656-661.

45. Zhang J, Zhang K, Jiang X, Zhang J (2014) S100A6 as a potential serum prognostic biomarker and therapeutic target in gastric cancer. Dig Dis Sci 59 2136-2144.

46. Lyu XJ, Li HZ, Ma X, Li XT, Gao Y, et al. (2015) Elevated S100A6 (Calcyclin) enhances tumorigenesis and suppresses CXCL14-induced apoptosis in clear cell renal cell carcinoma. Oncotarget 6: 6656-669.

47. Liang S, Xu Y, Shen G, Liu Q, Zhao X, et al. (2009) Quantitative protein expression profiling of 14-3-3 isoforms in human renal carcinoma shows 14-3-3 epsilon is involved in limitedly increasing renal cell proliferation. Electrophoresis 30: 4152-4162.

48. Dominguez R, Holmes KC (2011) Actin structure and function. Annu Rev Biophys 40: 169-186. 